\title{
Collective Perception of Anthropic and Extractive Interventions in the Colombian Llanos
}

\author{
Luca Eufemia ${ }^{1,2, *}$, , Hector Morales ${ }^{1,2}$, Michelle Bonatti ${ }^{1,2}$, Maximilian Graser ${ }^{2}$, Marcos Lana ${ }^{3}$ \\ and Stefan Sieber ${ }^{1,2}$ \\ 1 Department of Agricultural Sciences, Humboldt University, Invalidenstraße 42, 10099 Berlin, Germany \\ 2 SusLAND: Sustainable Land Use in Developing Countries, Leibniz Centre for Agricultural Landscape \\ Research (ZALF e. V), Eberswalder Str. 84, 15374 Müncheberg, Germany \\ 3 Department of Crop Production Ecology, Swedish University of Agricultural Sciences, Box 7044, \\ 76007 Uppsala, Sweden \\ * Correspondence: luca.eufemia@zalf.de
}

Received: 19 July 2019; Accepted: 5 September 2019; Published: 9 September 2019

\begin{abstract}
Increasingly, the developmental model of anthropic and extractive interventions is a global concern. Its impacts are challenging not only the precarious equilibrium of natural resources but also the one of local communities and identities. The case of the Colombian Llanos shows how the local culture of the Cultura Llanera (CL) is deep-rooted with natural resources, their use and their management. Throughout the use of a survey based on the Governance Analytical Framework (GAF), this paper presents and discusses shared problems and social norms. The collective perception of local groups shows that the $\mathrm{CL}$, in particular traditional livestock practices in flooded savannahs, is a key element for the sustainable development of the region. Furthermore, it reveals that agricultural and extractive activities, primarily rice and oil, are considered the main threats to both the ecosystem and the protection of the CL.
\end{abstract}

Keywords: governance models; Colombian Llanos; Cultura Llanera; extractivism

\section{Introduction}

Increasingly, the developmental model of anthropic and extractive interventions is a global concern. Its impacts are challenging not only the precarious equilibrium of natural resources but also those of local communities and identities. Within the complexity of sustainable development, broadening academic approaches in order to account for socio-economic and cultural perspectives is required. This work addresses the concept of development with regard to problem framing, which focuses on the interconnectedness of socio-ecological-cultural issues and their impact on the use and management of natural resources (Vandenberghe 1999). In the flooded savannahs of the Colombian Llanos, located in the east of Colombia, next to the border with Venezuela, we focus on the collective perception of anthropic and extractive interventions (e.g., the agricultural expansion and exploitation of hydrocarbons, including oil) and the link between natural resources and the local culture, known as Cultura Llanera $(\mathrm{CL})$. There is a lack of literature about the role and impacts of such interventions on local societal and cultural dynamics, as well as the understanding of the intrinsic relation between the depletion of natural resources and the erosion of local cultures in Colombia. However, many cases worldwide demonstrate that local cultures and functioning traditional institutions are important for sustainable development (Azamar Alonso and Ponce Sánchez 2015; Leff 2006; Ostrom 1990; Steelman and Carmin 1998). Considering the characteristics of the group that is dealing with the natural resource (e.g., the exploitation of wetlands for livestock farming), common shared norms and joint successful experiences are key aspects of a fruitful management of the resource (Frey 2018). The significance of 
local cultures and traditional institutions as ingredients for a prosperous and conserving development is also incorporated in the theories of local and indigenous knowledge. Therefore, the integration of social and cultural institutions into resource exploitation and use is needed to ensure a sustainable development (DeWalt 1994; Escobar 1999). As for our case study, previous studies demonstrate that traditional livestock practices based local knowledge in the flooded savannahs of the Colombian Llanos can be an opportunity for conservation (Peñuela et al. 2014; Peñuela and Fernández 2010; Uzzell and Badenas 2002).

From this, the way communities perceive the impact of anthropic and extractive interventions shapes the way they relate to new environments, both physical and intimate (Heft 1997). This implication may affect traditional knowledge and local culture. In the context of this research, when this concept entails cultural identity and the relation with the space or environment (e.g., the flooded savannahs ecosystem), the role of collective perception (e.g., of anthropic and extractive interventions) can help shape new paradigms for sustainable governance models and development (Bonatti 2011; Lander 2014; Peñuela et al. 2014; Peñuela and Fernández 2010; Steelman and Carmin 1998). For this reason, we choose to apply the tools of the Governance Analytical Framework (GAF), as they address collective perception in socio-ecological research. This paper contributes to the body of knowledge on the social constructions of community-shared concepts with respect to the role played by environmental, socio-historical, and economic processes. With this research, we expect a better understanding of the community roles, norms and rules regarding internal and external actors.

Therefore, we focus on perception and representation studies, where collective voices (e.g., the understanding and reactions to risks and problems) depend on different characteristics and relations (cultural, historical, political, etc.) (Bonatti 2011). The notion of perception is here associated with judgments, assignments, memories, emotion, motivation, representations of the environment, and meanings of social structure reproduction (Bonatti 2011; Heft 1997; Merleau-Ponty 1996; Steelman and Carmin 1998). The concept of spatial awareness and consciousness helps us to understand how space is not the real or logical place within which things are located, but the environment in which the position of things is possible (Merleau-Ponty 1996). From this point of view, space is not an abstract element in which things are suspended, but the universal power of their connections. One can stand between objects and consider space as their natural environment or, simply, as their common attribute. Apart from that, one can capture the nature of space as a subject and its interiority. Even before one's individual existence, space existed only in relation to a subject that one perceives.

From the intimate subjectivity to a broader group or sectorial representation of the collective perception of the issues at stake, we aim to understand how the identity of the CL is threatened, affected, and challenged by structural changes/anthropic and extractive interventions (e.g., extractive patterns of development vs. traditional ones). The place-related social and cultural identity, expressed in both the collective and individual relationship with geophysical and geographical space, may form an important dimension of environmental attitudes. Anthropic and extractive interventions are multiscale and multidimensional, as are the organizational practices that emerge around the territory (Duarte Ospina 2018; Uzzell and Badenas 2002). A number of scholars and authors look into the social constructions of community-shared concepts with respect to the role played by environmental, socio-historical, and economic processes (Bonatti 2011; Floriani 2003; Heft 1997; Jodelet 1986; Moscovici 1988; Steelman and Carmin 1998). In this paper, our research questions seek to observe the role of the CL as a key element for sustainable development in the Colombian Llanos. Likewise, we investigate if, according to groups' perceptions, agricultural and extractive activities are perceived as threats to the ecosystem and the erosion of the CL. A consistent literature, except for specific cases on Colombia, supports both hypotheses and provides empirical data on similar cases in different regions (Acosta 2013; Acuña 2015; Arsel et al. 2016; Avc1 2017; Chiasson-LeBel 2016; Gudynas 2009; Hempel 1996; Ostrom 1990; Salazar Ramírez 2017; Van Teijlingen 2016). From this, the objective of this paper is to fill this knowledge gap and to explore local group's perceptions of anthropic and extractive interventions, and their impact on the region and on the CL. Such a contribution includes 
the understanding of the local values and respective perception that constitute a basic condition of sustainable development (Vandenberghe 1999).

\section{Materials and Methods}

\subsection{Case Study Description}

Los Llanos is a region of South America divided between Colombia and Venezuela in the Orinoco basin. The biome is characterized by a vegetation of floodplain steppes, gallery forests, and a myriad of subunits, such as the sub-Andean jungle, wind plains, etc. (Ostrom 1990). It has two distinct seasons, the rainy season and the dry season, and it is characterized by its extensive, diverse, and heterogeneous savannahs (WWF 2017). Its climate is intertropical savannah (Fajardo and Urbina 1998). The economy in Los Llanos is mainly based on extensive livestock farming and oil extraction (Huertas 2014). During the 1970s, just $2 \%$ of the eastern plains of the Orinoco basin had been affected by significant land use changes. However, due to anthropic and extractive interventions, by 2012 the transformation of the region already reached $15.5 \%$, resulting in a drastic decrease of natural flooded savannahs from $11,401 \mathrm{~km}^{2}$ to $9283 \mathrm{~km}^{2}$ (18.5\%) (WWF 2017). These severe changes have negative impacts on the biological and cultural diversity in the Llanos, including the loss of habitat due to the expansion of extractive interventions, intensive agriculture, water and soil contamination, the introduction of non-native species, and the growing threat of climate change (Lander 2014; Peñuela et al. 2014). Casanare is one of the departments of the Colombian Llanos and is our focus, since the results of this work were extrapolated in two towns of the department, Yopal and Paz de Ariporo. Since 1990, the strengthening of extractive models not only configured a specific form of development that responds to the demands of capitalism, but also negatively affected the relationship between the local culture and the use and management of natural resources (Duarte Ospina 2018). Also as a result of the oil crisis, the socio-territorial and environmental effects in the territory have started to come to light only in 2008. Unclear land rights and speculation caused negative impacts on the ecosystems, generating social conflicts between extractive firms and locals, including peasants. The defense of organized communities has always incorporated the preservation of the $\mathrm{CL}$, as well as its factors of identity and land-use management. In the past decade, local movements mobilized for water provision, biodiversity conservation and better land-use practices. The role of the state was exercised at several scales: from its local institutions up to the framework of legislations that facilitate the actions and investments of the transnational companies in the territory. The role of the state in the territorial configuration and the implementation of a development model based on extractive activities have generated the gradual erosion of elements of the CL, confining it to its elements of folklore (Duarte Ospina 2018; Hincapié 2017). Within this context, the role of traditional and extensive livestock farming is an important element of identity of the CL (Caro-Caro et al. 2015). The low impact on natural resources, together with the conservation of the biodiversity, is part of a process lasting almost 500 years, developed in a historical context of territorial occupation, in coexistence with the seasonal dynamics of the savannah landscape and with the native flora and fauna (DNP 2014; Huertas 2014; Molano 1998; Peñuela et al. 2014).

Traditional productive models, including livestock farming, have contributed to the construction and reinforcement of the $\mathrm{CL}$, and they are key to understanding the development processes of the extractive industries and their impacts in the region. In the past years, external economic and extractive forces have prevailed over clear guidelines for sustainable development (local knowledge, resources, biodiversity, policies, etc.) (Duarte Ospina 2018). Likewise, issues of ambiguous land tenure regulations and the lack of infrastructure have contributed to the low productivity rate of local meat activities and production (Peñuela et al. 2014; Ruiz 2014). In Casanare in particular, there are few studies and alternatives that exist to contribute to the improvement of the productivity of local livestock farming in the flooded savannah. From the perspective of community identity related to traditional livestock, cultural practices such as local dances (e.g., joropo) and, in particular, work songs are also challenged 
by land-use changes and management. The melodies, transmitted orally through generations, resemble topics related to cattle ranching and grazing. Collective stories tune with the natural environments and their dynamics (Cobos 1966). Anthropic and extractive interventions are weakening these practices as the traditional way of life of communities embedded in the CL is changing (UNESCO 2017).

\subsection{Methodological Procedures}

To explore what local groups perceive about anthropic and extractive interventions as well as how these interventions challenge the identity of the CL, we follow the methodological approach of GAF (Hufty 2011). This instrument helps us to describe the relations between human interactions and the ecosystem. Because of its broad adaptability and applicability on the ground, the GAF allows researchers to describe socio-ecological processes within specific and unique contexts. It is used in qualitative research, and it comprises five analytical tools: problems, actors, social norms, processes, and nodal points. Due to time constraints for our field study, we only used two: problems and social norms. We created a survey to analyze social interactions in which the actors identify collective problems and social norms as a system of formal and informal norms and duties (e.g., actions and sanctions). The questions in the survey were clustered into three main blocks: the clear expression of perceived current problems, a condition to be improved upon (collective problems); the historical and cultural values that identify the belonging to the geographical space (hard facts); and the historical patterns of socio-economical changes and development in the region (nature of the problem). In addition, we asked actors a clear action regarding what should be implemented to alleviate the impacts of those issues (response). Regarding social norms, we structured questions into two main clusters. One focused on formal and informal norms that ought to be appropriate and that are not (actions). The second focused on elements that reinforce and constrain local behavior in relation to the CL and the land use and management (positive and negative sanctions). As a result, the involvement of different actors and institutions in responding to shared problems is what defines a non-normative concept of governance (Hufty 2011). From this perspective, therefore, we aim to comprehend the role of groups' perceptions of collective problems and social norms in relation to the CL. All questions were formulated in the form of lists. This provided the respondents with the opportunity to rank suggested categories, from most to least relevant. To select participants, we applied a snowball networking sampling and selected local groups based on shared similar traits (e.g., work and involvement in the area of study), the inclusion of different sectors (e.g., civil society, public and private sectors) and expertise about the CL (Biernacki and Waldorf 1981). In the department of Casanare (Yopal and Paz de Ariporo), we interviewed 17 local groups (involving a total of 50 participants), representing the civil society, the public sector, and the private sector (see Appendix A). Each interview was authorized and transcribed, lasting between one and three hours.

\section{Results}

\subsection{Collective Problems}

Figure 1 presents the group's perception of problems. The results show that the agricultural expansion (mainly for rice cultivation) and the exploitation of fossil hydrocarbons (oil) are the two key problems perceived by the 50 participants who were interviewed. The hard facts behind such problems are linked to the erosion of the local sense of belonging to the land. The nature of the problem is perceived to be aligned with the historical entrance of extractive interventions in the area. As a response to these issues, the representatives of the public sector would strengthen eco-tourism, while the private sector would invest in better management practices, especially for livestock. Civil society would respond by raising awareness about sustainable land use practices, the role of ecosystem services, and biodiversity. The logic of Figure 1 is to visualize the centrality of the collective problem and its impact, while connecting it to the suggested solutions or responses. 


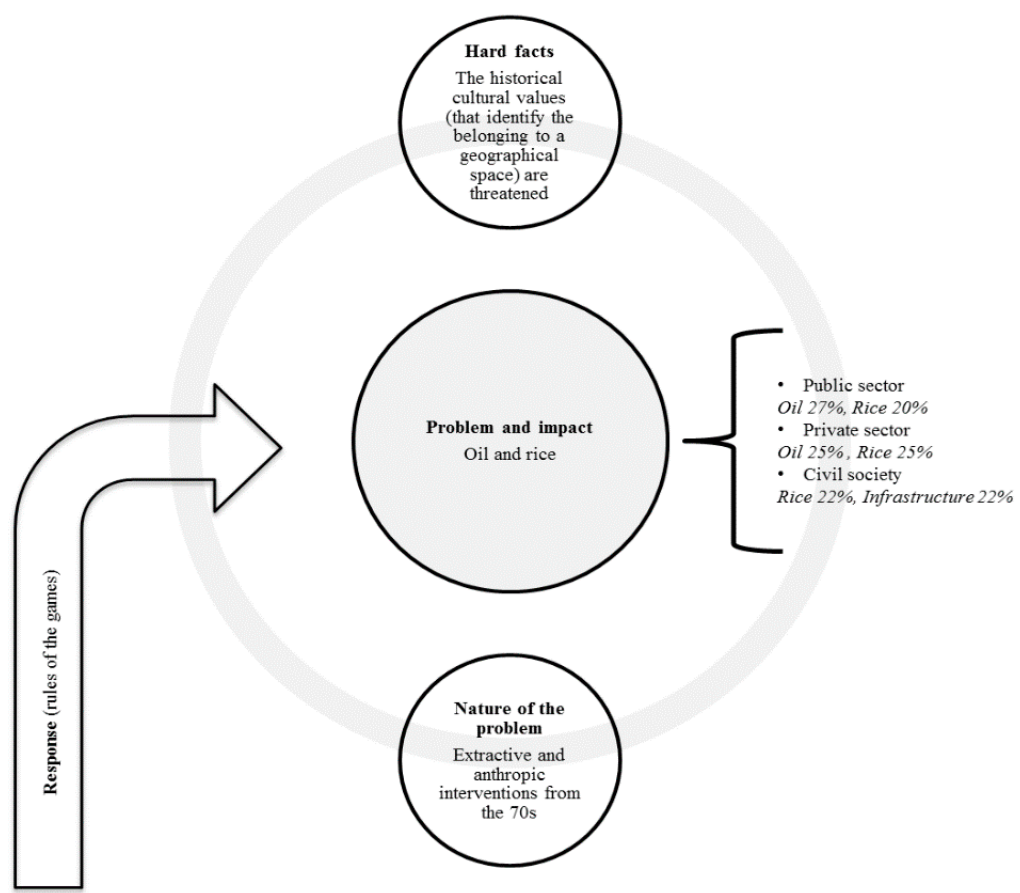

\begin{tabular}{cc}
\hline \multicolumn{2}{c}{ The suggested response of the three sectors involved } \\
\hline $\begin{array}{lc}\text { Public sector } \\
\text { Private sector } \\
\text { Civil society }\end{array}$ & Eco-tourism \\
\hline
\end{tabular}

Figure 1. The perceived problems of the 50 participants and their responses.

Table 1 presents the complete set of perceived problems in a ranking. By providing rates and rankings, this information aims to deliver a valid assessment of the results.

Table 1. The perceived problems (ranking).

\begin{tabular}{cc}
\hline Actors & Collective Problems \\
Oil $27 \%$ \\
Rice $20 \%$ \\
Uncontrolled fires $14 \%$ \\
Public Sector \\
The shift in cultural values $13 \%$ \\
Illegal immigration $12 \%$ \\
Drug abuse $7 \%$ \\
Prostitution $7 \%$ \\
Oil $25 \%$ \\
Rice $25 \%$ \\
Private Sector \\
Lack of environmental knowledge $13 \%$ \\
Uncontrolled fires $13 \%$ \\
Lack of infrastructure $14 \%$ \\
The political situation $10 \%$ \\
Rice $22 \%$ \\
Infrastructure $22 \%$ \\
Oil $19 \%$ \\
\hline Civil Society \\
\\
Unsustainable livestock farming $11 \%$ \\
Uncontrolled fires $7 \%$ \\
The shift in cultural values $7 \%$ \\
Oil palm plantations $4 \%$ \\
The political situation $4 \%$ \\
Hydrocarbon (other than oil) $4 \%$ \\
\hline Total 100\% \\
\hline
\end{tabular}




\subsection{Social Norms}

The results of social norms are divided into two key aspects: (1) actions, what ought to be appropriate and what is not; and (2) sanctions, both positive and negative. Both are based on tradition as well as formal, informal and customary rules. The results presented in Figure $2 \mathrm{a}, \mathrm{b}$, suggest that the most appropriate actions embedded in the CL are to maintain and preserve the creole bovine breed of the Llanos region and to rely on Community Action Boards, CAB (also known as juntas de acción comunal). The least appropriate actions to take are the grassland farming activities to replace native grass for an improved productivity. Regarding the role of positive sanctions, what emerges is that the lack of requirement and infrastructures to export meat abroad favors the relevance of regional and national markets. Nonetheless, the role of central and regional institutions (e.g., corruption) is perceived as a constraint for the protection of the CL. The logic of Figure 2 is to present the connection of appropriate actions versus non appropriate actions. Correspondingly, we wanted to visualize the connection of positive and negative sanctions.

Table 2 presents the complete set of perceived social norms in a ranking. By providing rates and rankings, this information aims to deliver a valid assessment of the results.

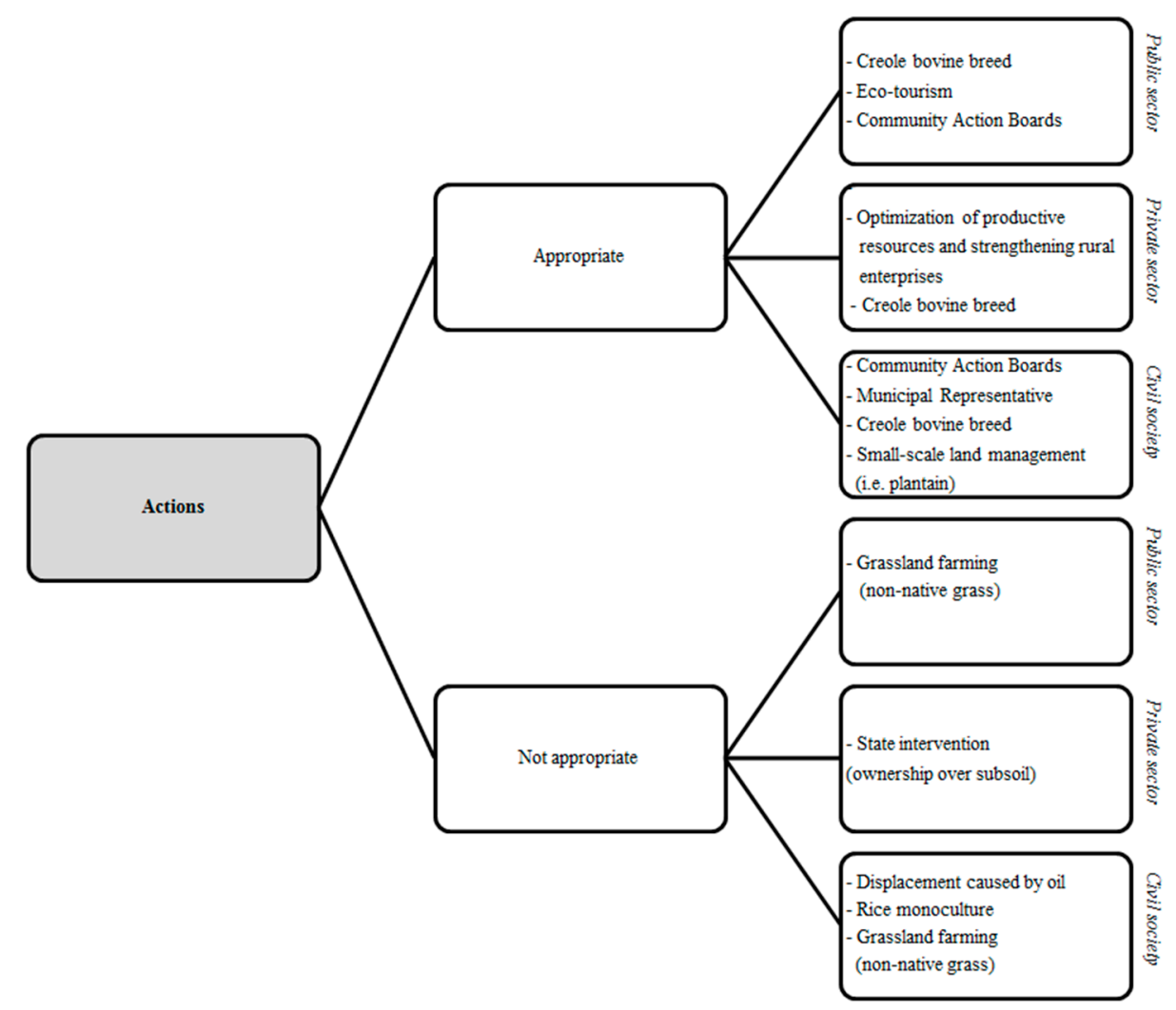

(a) Actions

Figure 2. Cont. 


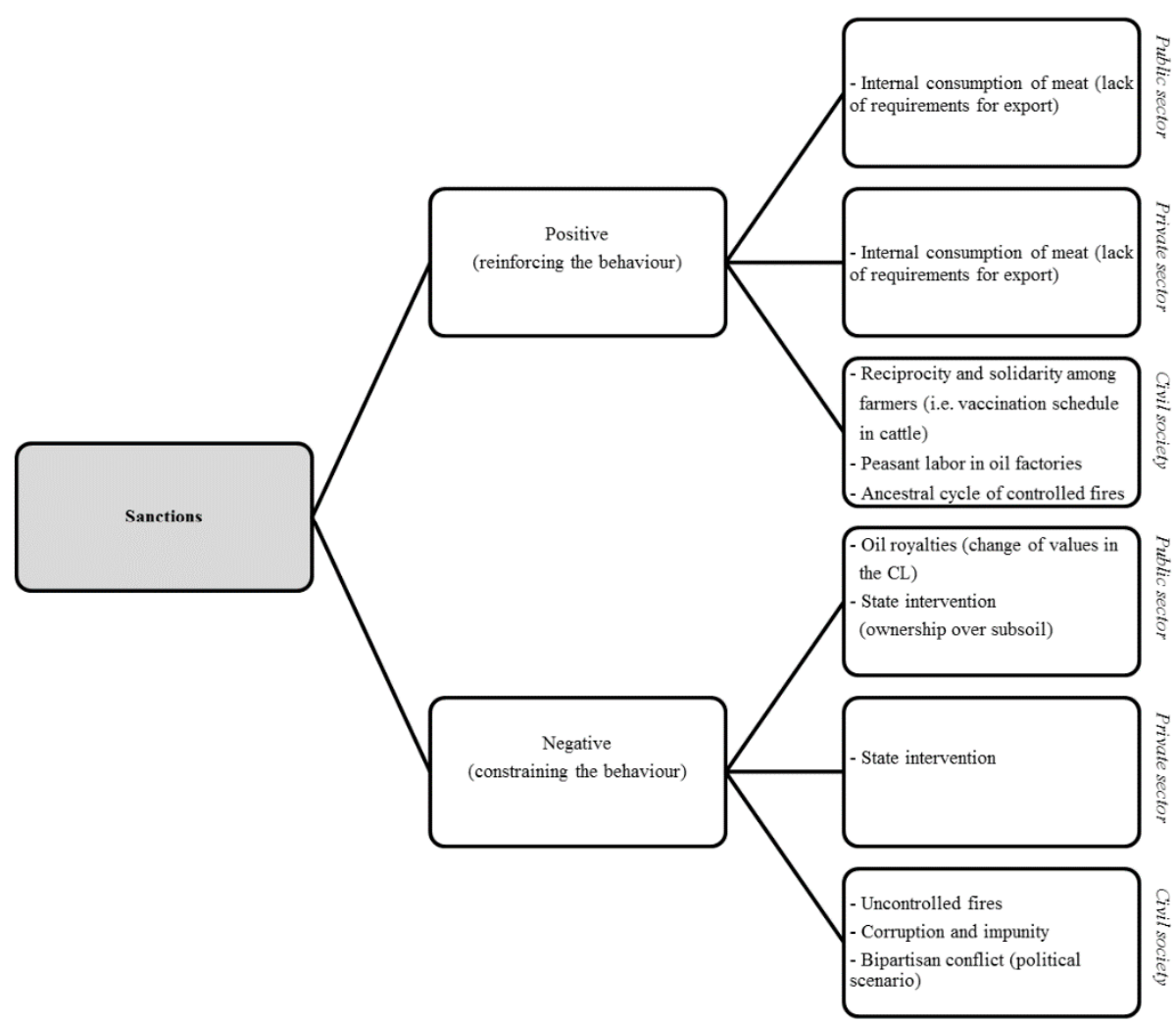

(b) Sanctions

Figure 2. The perceived social norms of local groups in relation to (a) actions and (b) sanctions.

Table 2. The perceived social norms (ranking).

\begin{tabular}{|c|c|c|c|c|}
\hline \multirow[t]{3}{*}{ Actors } & \multicolumn{4}{|c|}{ Social Norms } \\
\hline & \multicolumn{2}{|c|}{ Actions } & \multicolumn{2}{|c|}{ Sanctions } \\
\hline & Appropriate & Not appropriate & Positive & Negative \\
\hline $\begin{array}{l}\text { Public } \\
\text { Sector }\end{array}$ & $\begin{array}{ll}\text { - } & \text { Creole bovine breed } 41 \% \\
\text { - } & \text { Eco-tourism } 39 \% \\
\text { - } & \text { Community Action } \\
& \text { Boards CAB } 20 \%\end{array}$ & $\begin{array}{ll}\text { - } & \begin{array}{l}\text { Grassland farming } \\
\text { (non-native grass) } 78 \%\end{array} \\
\text { - } & \text { Others } 22 \%\end{array}$ & $\begin{array}{l}\text { - Internal consumption } \\
\text { of meat (lack of } \\
\text { requirements for } \\
\text { export) } 80 \% \\
\text { - Others } 20 \%\end{array}$ & 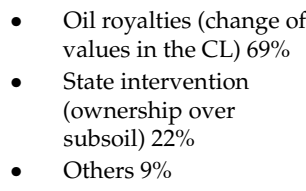 \\
\hline $\begin{array}{l}\text { Private } \\
\text { Sector }\end{array}$ & $\begin{array}{l}\text { - } \begin{array}{l}\text { Optimization of } \\
\text { productive resources } \\
\text { and strengthening rural } \\
\text { enterprises } 66 \%\end{array} \\
\text { - } \quad \text { Creole bovine breed } 29 \% \\
\text { - Others } 5 \%\end{array}$ & $\begin{array}{ll}\text { - } & \text { State intervention } \\
\text { (ownership over } \\
\text { subsoil) } 81 \% \\
\text { - } \quad \text { Land-tenure speculation } 15 \% \\
\text { - }\end{array}$ & $\begin{array}{l}\text { - Internal consumption } \\
\text { of meat (lack of } \\
\text { requirements for } \\
\text { export) } 69 \% \\
\text { - Others } 31 \%\end{array}$ & $\begin{array}{ll}\text { - } & \begin{array}{l}\text { State intervention } \\
\text { (ownership over }\end{array} \\
\text { subsoil) } 88 \% \\
\text { - } & \text { Others } 22 \%\end{array}$ \\
\hline $\begin{array}{l}\text { Civil } \\
\text { Society }\end{array}$ & $\begin{array}{ll}\text { - } & \text { CAB } 50 \% \\
\text { - } & \text { Municipal } \\
& \text { Representative } 22 \% \\
\text { - } & \text { Creole bovine breed } 20 \\
\text { - } & \text { Small-scale land } \\
& \text { management } \\
& \text { (i.e., plantain) } 6 \%\end{array}$ & $\begin{array}{ll}\text { - } & \text { Displacement caused by } \\
\text { oil } 42 \% \\
\text { - } & \text { Rice monoculture } 33 \% \\
\text { - } & \text { Grassland farming } \\
\text { (non-native grass) } 25 \%\end{array}$ & $\begin{array}{l}\text { Reciprocity and } \\
\text { solidarity among } \\
\text { farmers } \\
\text { (i.e., vaccination } \\
\text { schedule in cattle) } \\
60 \% \\
\text { - } \\
\text { Peasant labour in oil } \\
\text { factories } 26 \% \\
\text { - Ancestral cycle of } \\
\text { controlled fires } 14 \%\end{array}$ & $\begin{array}{ll}\text { - } & \text { Uncontrolled fires } 47 \% \\
\text { - } & \text { Corruption and } \\
\text { impunity } 39 \% \\
\text { - } & \text { Bipartisan conflict } \\
\text { (political scenario) } 14 \%\end{array}$ \\
\hline & & Total $100 \%$ & & \\
\hline
\end{tabular}




\section{Discussion}

The analysis of the collective perception of anthropic and extractive interventions presents the key perspective of collective issues at stake for the sample groups of the CL. Here, we discuss and compare the significance of the results of this research, underlining the core elements of the collective problems and social norms represented by the local groups. Under the lenses of perception approaches, we focus on the groups' individual experience of the world (e.g., CL) and its aspects (Heft 1997; Watts 2000). Reflections that societies make to identify opportunities to improve risk situations are built upon socio-economic, cultural historical and political characteristics, as well as on the nature of the problems causing risk situations (Bonatti 2011). The main limitation of the study regards the composition of the sample. Within the private and productive sectors, those who participated belong to the subsistence and livestock agricultural sector. None of the participants represented the agro or extractive industry (e.g., monoculture, hydrocarbons, etc.). This may cause some bias and heterogeneity of the results.

\subsection{Collective Problems}

The groups' perception of the collective problems is related to the increasing extractive developmental model, mostly relying on agricultural expansion (rice) and the exploitation of hydrocarbons (oil). These are perceived to be the main threats to the protection of the CL. The socio-economics of Casanare risk shifting into a complete reliance on activities such as rice and oil. The dependency on sole extractive interventions increases the environmental, domestic, and cultural vulnerability to fluctuations in the price of commodities on the world market (Azamar Alonso and Ponce Sánchez 2015). This is particularly problematic in the region of study as it becomes highly dependent on a few items or commodities. As such, the territorial space of Casanare is organized in a functional way, establishing practices, organizational processes, planning production, circulation and consumption, as well as specific and unequal power relationships that 'naturalize' and even legalize the dispossession of natural resources, intensifying the negative impacts on flooded savannahs (Díaz and Hilda 1998). This is causing the erosion of a local sense of belonging to the land in relation to its economic activities, especially with regard to traditional livestock. Cultural identity and traditional livestock practices in flooded savannahs have co-evolved with local flora and fauna, without a high anthropic impact of ecosystems (Reyes 2014). The fundamental criticism of the appropriation, privatization, and dispossession of natural resources, land and labor, is intimately related to the denaturalization of socio-spatial relationships that are established for the accumulation of capital (Delgado 2011). Land dispossession not only consists in the accumulation of land, but also in the loss of identity of local communities (Duarte Ospina 2018). In terms of the relation between the CL and environmentally sustainable economic development, all participants of this study agree upon the relevance of the environment and of physical space. The visualization of groups' collective problems, in the economic arrangements of rice and oil, goes parallel to the understanding of a speculative logic, not only in its extractive developmental model but also in its cultural and identity aspects (Azamar Alonso and Ponce Sánchez 2015). This homogeneity of perception may help in generating joint actions based on the understanding of the economic, cultural, political and historical processes of the collective problems, thus leveraging community participation (Heft 1997).

From these perspectives, public and private sectors share a similar perception on how to react to the main problems, while civil society aims at constructing a new perception and raising awareness. Nevertheless, the responses of the sample to collective problems aim both to reduce the negative impacts of extractivism and to find alternatives to it. All sectors relate their identity with the CL and recognize the threats of rice and oil. These can be justified by governmental planning in the region (e.g., the Policy for the Integral Development of the Orinoquia: Altillanura and the resolution on the new National Agricultural Frontier) that supports major changes of agricultural models (Caro-Caro et al. 2015; Eufemia et al. 2018; Peñuela et al. 2014). Governmental planning has promoted land-use changes since the 1990s with the construction of the first oil wells and, since the early 2000s, the expansion of agroindustry during the administration of President Uribe. Uribe's mandate 
portrayed the Orinoquia region as a blank canvas to be painted ("lienzo en blanco") (DNP 2007), a territory open to colonization, filled with opportunities for private investments. Furthermore, Orinoquia was presented as a territory that, in comparison to the Amazon region, does not have major environmental restrictions (Rodríguez et al. 2009). This vision of development included a major intervention of highways and infrastructure consigned as the "Programme for the Development of Highway Concessions 2006-2014" (DNP 2007), giving clear guidelines for land use (agroindustry, bio-fuel and hydrocarbons) and a predominant role to the international and national private sector at the detriment of local actors (Rodríguez et al. 2009). Academic experts from the region claim that there is a global financial strategy that determines a series of political, legal, regulatory, and economic instruments aimed primarily at land acquisition in order to carry out investments in biofuels and the development of hydrocarbon mining. Large-scale agro-industrial projects displaced small and medium scale peasants by pressuring them to sell as a consequence of land-market price speculation. The model provides advances in infrastructure and a temporary growth of the services economy with no productive transformation, which does not favor the diversification of economic activity in the region. In addition, it gives rise to migration phenomena that increase urban dynamics through the influx of transient, floating migrant populations (Caro-Caro et al. 2015; Franco 2015; Pardo 2015).

To provide tangible compensations, local groups would strengthen eco-tourism, improve better management practices in traditional livestock, and raise awareness about the importance of the ecosystem and its services. These are perceived to function as tools that value the CL in all its forms. The result may be forms of payment of socio-environmental costs and replacing what today is invested in subsidies with agricultural and extractive sectors (tax exemptions, cheap energy and royalties), possibly redirecting the workforce to traditional sectors (Aguilar 2013). For instance, voluntary schemes of private conservation that include those elements are in place in the region. The Natural Reserves of the Civil Society (RNSC) is the private category of conservation of the National System of Protected Areas (SINAP). It offers land owners, who are willing to conserve part of their land, the implementation of sustainable production projects that value the protection of the cultural heritage thorough eco-tourism and the inclusion of local knowledge (e.g., the incorporating of CL elements in better management practices for livestock farming, etc.). Moreover, depending on the financial capacity of each municipality, the owners could receive the exemption or reduction of property taxes. Besides, they can receive capacity building and technical support from environmental authorities or private organizations (Quintero López and Arbeláez 2016).

Local movements (including land owners, peasants, etc.) are carrier of the CL, generating the link between local knowledge and strategies of resistance for the defense or protection of their territory. These strategies promote forms of social and territorial relationships against extractive models. The resilience of local communities brings with it proposals aimed at strengthening the collective identity of the CL. Despite this, these are in constant tension with the state and extractive companies (Duarte Ospina 2018). Hence, alternatives and tendencies for a transition toward a post-extractivist scenario remain scarce, both in terms of land extension and financial incentives. While it is necessary to apply governance, as well as ecological and social improvements, which in some way reverse the damages that have been systematically caused by anthropic and extractive interventions, what groups are facing today is a lack of private and public will and investments in sustainable alternatives (Acosta 2013; Gudynas 2012).

\subsection{Social Norms}

Social norms integrated in the CL are both formal and informal. They form elements of social representation that function as a reaction to perceived problems. From the perspective of land use and the management of flooded savannahs, the critical importance of maintaining and preserving the creole bovine breed is perceived by the respondents as the most appropriate action for the protection of the CL because of its identity factor in the region. Due to the low productivity and economic profitability of such an action (e.g., continuous decreasing indicators of animal breeding 
and the economic incentives for extractive activities) within the regional ecosystem, its preservation is under threat. In this regard, approaches with the private category of conservation can be a viable opportunity for maintaining and preserving this social norm (e.g., The Natural Reserves of the Civil Society, RNSC). There are a few successful cases where cattle ranchers have optimized creole bovine breeding, economic and productive indicators in flooded savannahs, while favouring the conservation of biodiversity. As an example, by adding multi-nutritional energy block supplementation during the dry season, applying pasture rotation using electric fences and maintaining an optimal nutrient and water supply, farmers increase the forage biomass production, improving and maintaining traditional livestock farming on native pastures while reducing the risks of environmental degradation and biodiversity losses (by overgrazing and selective foraging) and maintaining acceptable profit levels (Peñuela and Fernández 2010; Sastre et al. 2010; Pava Vargas and Valencia 2018; Wilken 1990). This strategy is not only positive in relation to its creole bovine element, embedded in the culture and folklore of the CL, but also in terms of the improvement of the traditional system for a sustainable model of development. This approach goes hand-in-hand with the importance of the conservation and protection of native pastures, as their replacement for an improved productivity is perceived to be the least appropriate action to take.

From the standpoint of the existing legal system that could leverage the discourse on land use and management, the role played by the Community Action Boards (CAB) (also known as juntas de acción communal) represents an important form of legal norm-related action. These mechanisms are civic and non-profit, community-based organizations for social management. CAB are voluntarily integrated by the residents of a place, who join efforts and resources to seek a better life and sustainable development based on the principles of the exercise of participatory democracy. ${ }^{1}$ This effort should be encouraged by, among other things, the use of traditional concepts such as instruments of historical memory, the transformation of education to allow a dialogue of knowledge in a true intercultural exercise, solidarity and dignity in power relations, and, in this sense, a generalization of democracy beyond the electoral aspect (Aguilar 2013). Furthermore, institutional actors, such as the Municipal Procurement Office (also known as Personería Municipal), which are the representatives of the National Procurement Office (Ministerio Público-Procuraduría General de La Nación), are very important in encouraging, defending, protecting, and taking into account the public and collective interest, especially regarding environmental protection, human rights violations, and the conservation of public patrimony (cultural heritage $)^{2}$ from a formal/legal perspective. Nevertheless, the increasing focus on extractive resources since the early 2000s, such as oil, is generating a negative impact on the development of Casanare, lowering the institutional role of the CAB (Pava Vargas and Valencia 2018). The misconduct of the public sector in managing natural resources has generated a situation in which 15 governors have been replaced in only 12 years (Pava Vargas and Valencia 2018). Through the legal instruments of oil royalties, weak institutions have influenced the indexes of low competitiveness of the region, compared to others in Colombia with much less availability of natural resources and related royalties. In the past decade, oil royalties in Casanare have only contributed to $10 \%$ of the development of the region. This means an unprofitable deal and investment compared to the high amount of oil royalties per capita in Casanare (Pava Vargas and Valencia 2018).

From this context of norms to the context related to sanctions that are both positive and negative, what emerges is twofold. First, the opportunity of local and regional markets for traditional livestock production (also due to the lack of infrastructure) constitutes a valid alternative to the preponderance of extractivist activities. To regain the sovereignty of local territories and knowledge (e.g., traditional cattle ranching in flooded savannahs), the role of the experiences of local cultures should be better recognized by central and local governments and institutions (Gonçalves 2001; Hoogesteijn and

1 República de Colombia. Ley 743 de 2002. Art. 8. Available online: https://www.mininterior.gov.co/sites/default/files/36_ley_ 743_de_2002.pdf (retrieved 6 November 2018).

2 Constitución Política de Colombia. 1991. Art. 178. 
Hoogestein 2010; Martínez-Alier 2004). For instance, approaches to preserve the creole bovine breed and traditional know-how activities of cattle ranchers, such as small-scale polyculture farming (known as conuco), ancestral cycles of controlled fires, solidarity rounds of animal vaccinations, and manure and water dispenser application methods (known as tópochera and tapas), may be an initial basis of expertise and knowledge exchange and valorization. Besides, these approaches foster the concepts of both place-related socio-cultural identity and the understanding of local values (Peñuela et al. 2014; Uzzell and Badenas 2002; Vandenberghe 1999). This could lead to the construction of a new paradigm of development that is collective and in a balanced social dynamic among people, genders, and social groups (Aguilar 2013). Second, the negative impact of corruption at all levels feels like a negative sanction that is coercing the CL. Thus, the territory becomes an element of dispute between the actors who live in it; likewise, the territory is also an axis that configures identities around it.

In this sense, the extractive model consolidates scenarios of inequality based on the development of extractive activity and its effects. Instead, territorial proposals that the communities make should reinforce local knowledge in the face of the complex interaction between nature and culture (Duarte Ospina 2018). Likewise, the response to sanctions should aim at the collective and inclusive understanding of governments and institutions (national, regional and local), in which one seeks to strengthen the institutionalism and governability of the region. In this way, the formulation of alternative forms of diversifying the economy of the region may come into place, favoring not only the management of natural resources but also the protection of the CL (Pava Vargas and Valencia 2018).

\section{Conclusions}

This study focused on the collective perception of anthropic and extractive interventions in the flooded savannahs of the Colombian Llanos. The results confirm our initial assumptions that practices of the CL in the forms of traditional livestock in flooded savannahs, which includes strategies to optimize creole bovine breeding, economic and productive indicators for cattle ranchers, are key elements for the sustainable development of the region. Agricultural and extractive activities (rice and oil) are considered the main threats to both the ecosystem and the protection of the CL. Both results reveal that the spatial relation of local groups rooted in the CL is being increasingly threatened by decades of land-dispossessions, state-corruption, and the tendency to solely rely on one or two economic activities. Plans for future relevant research include an in-depth analysis of land-use change in the region and a comparison between the environmental impacts of traditional land use versus the ones of extractive activities. Similarly, social representation studies could leverage the relevance of our results and include the collective problems and social norms presented.

Author Contributions: Conceptualization, investigation, visualization and writing —original draft preparation, L.E.; methodology, L.E., M.B. and S.S.; validation, M.B., S.S., H.M.; formal analysis, L.E., H.M., M.B. and M.G.; data curation, L.E., H.M., M.B. and M.L.; writing—review and editing, L.E., H.M., M.B., M.G., S.S. and M.L.; supervision, S.S. and M.B.

Funding: This research is funded by a project of the International Climate Initiative (IKI). The Federal Ministry for the Environment, Nature Conservation and Nuclear Safety (BMU) supports this initiative on the basis of a decision adopted by the German Bundestag.

Acknowledgments: Our sincere thanks to the Fundación Horizonte Verde and World Wildlife Fund (WWF) offices of Colombia and Germany for providing their expertise.

Conflicts of Interest: The authors declare no conflict of interest. The funders had no role in the design of the study; in the collection, analyses, or interpretation of data; in the writing of the manuscript, or in the decision to publish the results. 


\section{Appendix A}

Table A1. Interviews in situ with 17 institutions/groups (50 participants).

\begin{tabular}{cc}
\hline Public Sector & N. Participants \\
\hline Medio Ambiente-Gobernación de Casanare (Yopal) & 2 \\
Municipality of Paz de Ariporo, Consejo de Cultura (Paz de Ariporo) & 2 \\
Municipality of Paz de Ariporo, “Familias en Acción” (Paz de Ariporo) & 7 \\
Secretaría de Agricultura, Ganadería y Medio Ambiente (Paz de Ariporo) & 1 \\
Ministry of Culture and Tourism (Paz de Ariporo) & 3 \\
\hline Total & $\mathbf{1 5}$ \\
\hline Private sector & 3 \\
\hline Comité Municipal de Ganaderos de Paz de Ariporo (Paz de Ariporo) & 6 \\
Fundación Salvaterra (Paz de Ariporo) & 5 \\
\hline Centro Eco-Turistico Golconda (Paz de Ariporo) & $\mathbf{1 4}$ \\
\hline Civil society & 3 \\
\hline ABC Asociación becarios del Casanare (Yopal) & 1 \\
WWF Colombia (Yopal) & 1 \\
\hline Fundación Reserva Natural La Palmita-Centro de Investigación (Yopal) & 4 \\
Bicentenario Presidente Moreno (Paz de Ariporo) & 1 \\
Enitrópico (Yopal) & 4 \\
Fundación Cunaguaro (Yopal) & 2 \\
Fundación Horizonte Verde (Yopal-Villavicencio) & 4 \\
Tautacos Caminantes del Llano (Paz de Ariporo) & 1 \\
\hline Comunidad de la vereda Centro Gaitán del municipio de Paz de Ariporo (Paz de Ariporo) & $\mathbf{2 1}$ \\
\hline
\end{tabular}

\section{References}

Acosta, Alberto. 2013. Extractivism and neo extractivism: Two sides of the same curse. Beyond Development: Alterniative Visions from Latin America 61: 61-86. [CrossRef]

Acuña, Roger Merino. 2015. The politics of extractive governance: Indigenous peoples and socio-environmental conflicts. Extractive Industries and Society 85: 1-92. [CrossRef]

Aguilar, Juliana Sabogal. 2013. Extractivismo Minero en Colombia, el Caso de Marmato-Caldas en clave de Ecología Política. In Ecología Política del Extractivismo en América Latina: Casos de Resistencia y Justicia Socio-Ambiental. Edited by Delgado Ramos, Gian Carlo and Eduardo Mondaca. Buenos Aires: CLACSO, pp. 171-90.

Arsel, Murat, Hogenboom Barbara, and Pellegrini Lorenzo. 2016. The extractive imperative in Latin America. Extractive Industries and Society 3: 880-87. [CrossRef]

Avc1, Duygu. 2017. Mining conflicts and transformative politics: A comparison of Intag (Ecuador) and Mount Ida (Turkey) environmental struggles. Geoforum 84: 316-25. [CrossRef]

Azamar Alonso, Aleida, and José Ignacio Ponce Sánchez. 2015. El neoextractivismo como modelo de crecimiento en América Latina. Economía y Desarrollo 154: 185-98. Available online: http://scielo.sld.cu/scielo.php?pid= S0252-85842015000200014\&script=sci_arttext\&tlng=pt (accessed on 15 March 2018).

Biernacki, Patrick, and Dan Waldorf. 1981. Snowball sampling: Problems and techniques of chain referral sampling. Sociological Methods and Research 10: 141-63. [CrossRef]

Bonatti, Michelle. 2011. Cambios Climáticos, Percepciones Humanas y Desarrollo Rural. Buenos Aires: Universidad de Buenos Aires.

Caro-Caro, Clara Inés, Benavides-Ladino Gustavo Fidel, Marco Aurelio Torres-Mora, and Sandra Parada-Guevara. 2015. Visión de Visiones del Desarrollo Sostenible de los Llanos Orientales. Las Voces de los Territorios. Edited by Instituto de Ciencias Ambientales de la Orinoquia Colombiana. Villavicencio: Unillanos, pp. 15-55.

Chiasson-LeBel, Thomas. 2016. Neo-extractivism in Venezuela and Ecuador: A weapon of class conflict. Extractive Industries and Society 3: 888-901. [CrossRef] 
Cobos, María Teresa I. 1966. Del habla popular en el Llano. Boletín Cultural y Bibliográfico 11: 5. Available online: https://publicaciones.banrepcultural.org/index.php/boletin_cultural/article/view/4701/4934 (accessed on 2 January 2018).

Delgado, Ramos. 2011. Bienes Comunes, Metabolismo Social y el Futuro común de la Humanidad: Un Análisis Norte-Sur. Documento Temático de la Conferencia Sobre los Bienes Comunes en Roma 28 y 29 de Abril. Rome: Fundación Rosa Luxemburg Bruselas.

Departamento Nacional de Planeación (DNP). 2014. Política para el Desarrollo Integral de la Orinoquia: Altillanura. Available online: https://ceo.uniandes.edu.co/images/Documentos/Conpes\%20Altillanura\% 202014.pdf (accessed on 1 October 2018).

Departamento Nacional de Planeación (DNP). 2007. Plan Nacional de Desarrollo 2006-2010. Estado Comunitario: Desarrollo Para Todos. Available online: https://colaboracion.dnp.gov.co/cdt/pnd/pnd_tomo_2.pdf (accessed on 1 October 2018).

DeWalt, Billie. 1994. Using Indigenous Knowledge to Improve Agriculture and Natural Resource Management. Human Organization 53: 123-31. Available online: http://iks.ukzn.ac.za/sites/default/files/47re.pdf (accessed on 11 January 2018). [CrossRef]

Díaz, G., and Lucía Hilda. 1998. La Cultura Llanera: Un análisis etno-semiótico. Colombia Orinoco 1: $259-69$. Available online: http://www.bdigital.unal.edu.co/7436/ (accessed on 20 March 2018).

Duarte Ospina, Juliana. 2018. Desarrollo, Extractivismo Petrolero y Transformaciones Socioterritoriales en el Municipio de Aguazul, Casanare (Colombia) 1990-2015. Doctoral dissertation, Universidad Nacional de Colombia-Sede Bogotá, Bogotá, Colombia. Available online: http://bdigital.unal.edu.co/64701/1/1020748597. 2018.pdf (accessed on 4 July 2019).

Escobar, Arturo. 1999. El Final del Salvaje: Naturaleza, Cultura y Política en la Antropología Contemporánea. Bogotá: Cerec.

Eufemia, Luca, Michelle Bonatti, and Marcos Alberto Lana. 2018. Colombia's rural development must honour peace agreement. Nature 560: 7716. Available online: https://www.nature.com/articles/d41586-018-05847-x (accessed on 1 August 2018). [CrossRef] [PubMed]

Fajardo, Darío, and Fernando Urbina. 1998. Colombia Orinoco. Bogotá: FEN.

Floriani, Dimas. 2003. Conhecimento, Meio Ambiente e Globalização. Curitiba: Juruá Editora.

Franco, Santiago. 2015. Ciudades y crecimiento urbano sostenible. In Unillanos-Biotopo: Mesa-Taller de Expertos Para la Construcción Participativa de la Visión de Desarrollo Sostenible de la Orinoquia Colombiana. Edited by Instituto de Ciencias Ambientales de la Orinoquia Colombiana. Villavicencio: Unillanos, pp. 3-16.

Frey, Ulrich. 2018. Nachhaltige Bewirtschaftung Natürlicher Ressourcen-Erfolgsfaktoren in Komplexen Sozial-ökologischen Systemen. Berlin: Springer Spektrum.

Gonçalves, Carlos Walter Porto. 2001. Geografías: Movimientos Sociales, Nuevas Territorialidades y Sustentabilidad. Ciudad de México: Siglo XXI.

Gudynas, Eduardo. 2009. Diez tesis urgentes sobre el nuevo extractivismo. Extractivismo, Política y Sociedad 187: 225. Available online: http://www.rosalux.org.ec/pdfs/extractivismo.pdf\#page=187 (accessed on 15 June 2018).

Gudynas, Eduardo. 2012. Alternativas a la sobreexplotación de los recursos naturales: Hay vida después del extractivismo. In Pobreza, Desigualdad y Desarrollo: Informe Perú. Lima: OXFAM Informe Perú 2011/2012, pp. 44-53.

Heft, Harry. 1997. The Relevance of Gibson's Ecological Approach to Perception for Environment-Behaviour Studies. In Toward the Integration of Theory, Methods, Research, and Utilization. Edited by Gary T. Moore and Roberto W. Marans. Boston: Springer, volume 4, pp. 71-108.

Hempel, Lamont C. 1996. Environmental Governance: The Global Challenge. Washington: Island Press.

Hincapié, Sandra. 2017. Extractivismo, consultas populares y derechos políticos: El renacimiento de la democracia local en Colombia? Reflexión Política 19: 86-99. [CrossRef]

Hoogesteijn, Almira, and Rafael Hoogestein. 2010. Cattle ranching and biodiversity conservation as allies in South America's flooded savannas. Great Plains Research, 37-50. Available online: https://www.jstor.org/stable/ 23782174 (accessed on 10 February 2018).

Huertas, Hugo. 2014. Relación de complementariedad sabana inundable y ganadería. In Sabana Inundable y Ganadería, Opción Productiva de Conservación en la Orinoquia. Edited by Lourdes Peñuela. Villavicencio: Fundación Horizonte Verde, pp. 27-45. 
Hufty, Marc. 2011. Investigating Policy Processes: The Governance Analytical Framework (GAF). In Research for Sustainable Development: Foundations, Experiences, and Perspectives. Edited by Urs Martin Wiesmann and Hans Hurni. Bern: NCCR North-South/Geographica Bernensia, pp. 403-24.

Jodelet, Denise. 1986. La representación social: Fenómenos, concepto y teoría. In Psicología Social II. Edited by Serge Moscovici. Buenos Aires: Psicología Social, Pensamiento y Vida Social, pp. 469-94.

Lander, Edgardo. 2014. El Neoextractivismo Como Modelo de Desarrollo En América Latina y sus Contradicciones. Berlin: Fundación Heinrich Böll.

Leff, Enrique. 2006. La Ecología Política en América Latina: Un Campo en Construcción. Brasília: Sociedade e Estado, pp. 17-40.

Martínez-Alier, Joan. 2004. Los conflictos ecológicos-distributivos y los indicadores de sustentabilidad. Revista Iberoamericana de Economía Ecológica 1: 21-30. Available online: https://ddd.uab.cat/record/4860 (accessed on 11 March 2018).

Merleau-Ponty, Maurice. 1996. Phenomenology of Perception. Delhi: Motilal Banarsidass.

Molano, Joaquín. 1998. Biogeografía de la Orinoquia Colombiana. In Colombia Orinoco. Edited by Darío Fajardo Montaña and Fernando Urbina Rangel. Bogotá: FEN, pp. 75-119.

Moscovici, Serge. 1988. Notes towards a description of social representations. Journal of European Social Psychology 18: 211-50. [CrossRef]

Ostrom, Elinor. 1990. Governing the Commons: The Evolution of Institutions for Collective Action. Cambridge: Cambridge University Press.

Pava Vargas, Andrés Fernando, and Alberto Lemos Valencia. 2018. Los efectos socioeconómicos de las regalías petroleras en el departamento de Casanare, periodo 2004-2015. Apuntes del Cenes 37: 66. Available online: http: //www.scielo.org.co/pdf/cenes/v37n66/0120-3053-cenes-37-66-239.pdf (accessed on 4 April 2018). [CrossRef]

Pardo, Antonio. 2015. Los Recursos Naturales no Renovables en una Nueva Perspectiva Regional de los Llanos Orientales de Colombia. Villavicencio: Instituto de Ciencias Ambientales de la Orinoquia Colombiana.

Peñuela, Lourdes, and Andrea Fernández. 2010. La ganadería ligada a procesos de conservación en la sabana inundable de la Orinoquia. Orinoquía 14: 5-17.

Peñuela, Lourdes, Clara Solano, Ardila Vanessa, and Sandra Galán. 2014. Conservación de la biodiversidad en predios productivos. In Sabana Inundable y Ganadería, Opción Productiva de Conservación en la Orinoquia. Edited by Lourdes Peñuela. Villavicencio: Fundación Horizonte Verde, p. 230.

Quintero López, Melissa, and Fabio Alberto Arias Arbeláez. 2016. Nature conservation on private land: Natural Reserves of Civil Society in Valle del Cauca. Apuntes del Cenes 35: 17-48. [CrossRef]

Reyes, María Lucila. 2014. Aportes y percepciones de los ganaderos de la sabana inundable. In Sabana Inundable y Ganadería, Opción Productiva de Conservación en la Orinoquia. Edited by Lourdes Peñuela. Villavicencio: Fundación Horizonte Verde, pp. 167-77.

Rodríguez, Manuel, Germán Andrade, Luis Castro, Armando Durán, Guillermo Rudas, Eduardo Uribe, and Eduardo Wills. 2009. La Mejor Orinoquia que Podemos Construir-Elementos para la Sostenibilidad Ambiental del Desarrollo. Bogotá: Corporinoquia-Universidad de los Andes-Foro Nacional Ambiental-Friedrich Ebert Stiftung (FESCOL).

Ruiz, Maynor. 2014. Oportunidades del ordenamiento del territorio basado en la sostenibilidad. In Sabana Inundable y Ganadería, Opción Productiva de Conservación en la Orinoquia. Edited by Peñuela Lourdes. Villavicencio: Fundación Horizonte Verde, pp. 137-63.

Salazar Ramírez, Hilda. 2017. El extractivismo desde el enfoque de género: una contribución en las estrategias para la defensa del territorio. Sociedad y Ambiente 13: 35-37. Available online: http://revistas.ecosur.mx/ sociedadyambiente/index.php/sya/article/view/1754/1677 (accessed on 22 May 2018).

Sastre, Héctor Julio, Evangelina Rodero, Antonio Rodero, Mariano Herrera, and Francisco Peña. 2010. Caracterización etnológica y propuesta del estándar para la raza bovina colombiana Criolla Casanare. Animal Genetic Resources/Resources Génétiques Animales/Recursos Genéticos Animales 46: 73-79. [CrossRef]

Steelman, Toddi A., and Joann Carmin. 1998. Common property, collective interests, and community opposition to locally unwanted land uses. Society and Natural Resources 11: 485-504. [CrossRef]

UNESCO. 2017. Cantos de Trabajo de Los Llanos de Colombia y Venezuela. Available online: https://ich.unesco. org/es/USL/cantos-de-trabajo-de-los-llanos-de-colombia-y-venezuela-01285 (accessed on 14 March 2018).

Uzzell, David, and David Badenas. 2002. Place identification, social cohesion, and enviornmental sustainability. Environment and Behavior 34: 26-53. [CrossRef] 
Van Teijlingen, Karolien. 2016. The 'will to improve' at the mining frontier: Neo-extractivism, development and governmentality in the Ecuadorian Amazon. Extractive Industries and Society 3: 902-11. Available online: https://www.sciencedirect.com/science/article/pii/S2214790X16301848 (accessed on 13 March 2018). [CrossRef]

Vandenberghe, Frédéric. 1999. The Real is Relational: An epistemological analysis of Pierre Bourdieu's generative structuralism. Sociological Theory 17: 32-67. [CrossRef]

Watts, Michael. 2000. Political Ecology. In A companion to Economic Geography. Edited by Eric Sheppard and Trevor Barnes. Oxford: Blackwell, pp. 257-74.

Wilken, Gene C. 1990. Good Farmers: Traditional Agricultural Resource Management in Mexico and Central America. Berkeley: Univ of California Press.

WWF. 2017. Colombia Viva: Un País Megadiverso de Cara al Futuro. Available online: https://d2ouvy59p0dg6k. cloudfront.net/downloads/colombia_viva_informe_2017_1.pdf (accessed on 2 February 2018).

(C) 2019 by the authors. Licensee MDPI, Basel, Switzerland. This article is an open access article distributed under the terms and conditions of the Creative Commons Attribution (CC BY) license (http://creativecommons.org/licenses/by/4.0/). 